\title{
The inevitable duality of education: cooperative higher education
}

Citation for published version (APA):

Kirschner, P. A. (2000). The inevitable duality of education: cooperative higher education. Maastricht University, Unigraphic. https://doi.org/10.26481/spe.20000623pk

Document status and date:

Published: 23/06/2000

DOI:

10.26481/spe.20000623pk

Document Version:

Publisher's PDF, also known as Version of record

\section{Please check the document version of this publication:}

- A submitted manuscript is the version of the article upon submission and before peer-review. There can be important differences between the submitted version and the official published version of record.

People interested in the research are advised to contact the author for the final version of the publication, or visit the DOI to the publisher's website.

- The final author version and the galley proof are versions of the publication after peer review.

- The final published version features the final layout of the paper including the volume, issue and page numbers.

Link to publication

\footnotetext{
General rights rights.

- You may freely distribute the URL identifying the publication in the public portal. please follow below link for the End User Agreement:

www.umlib.nl/taverne-license

Take down policy

If you believe that this document breaches copyright please contact us at:

repository@maastrichtuniversity.nl

providing details and we will investigate your claim.
}

Copyright and moral rights for the publications made accessible in the public portal are retained by the authors and/or other copyright owners and it is a condition of accessing publications that users recognise and abide by the legal requirements associated with these

- Users may download and print one copy of any publication from the public portal for the purpose of private study or research.

- You may not further distribute the material or use it for any profit-making activity or commercial gain

If the publication is distributed under the terms of Article $25 \mathrm{fa}$ of the Dutch Copyright Act, indicated by the "Taverne" license above, 


\section{The inevitable duality of education:}

\section{Cooperative higher education}

\section{INAUGURAL ADDRESS}

spoken upon the acceptance of the position of

Professor of Contact and Distance Education

at Maastricht University

on Friday, June 23, 2000

by

Prof. dr. Paul A. Kirschner 
For Catharine, Femke, Jesse, Mara and Aron

You are the unity in my cluttered duality

The real voyage of discovery consists not in seeking new landscapes, but in having new eyes.

Marcel Proust (1871-1922)

As soon as you give it up you can have it all. Ram Dass (Richard Alpert)

CIP-GEGEVENS KONINKLIJKE BIBLIOTHEEK, DEN HAAG

The inevitable duality of education: Cooperative higher education

Paul Kirschner

Maastricht: Unigraphic, 2000, 36 pages including references and notes

ISBN: $90-5681-077 \cdot 4$

All rights reserved. No part of this book may be reproduced in any form, by print, photocopy, microfilm or any other means without the written permission of the author. 
Mister vice-chancellor / Mijnheer de Rector Magnificus,

Colleagues,

Family and friends,

Ladies and gentlemen,

Look at the following well known optical illusion. What do you see?
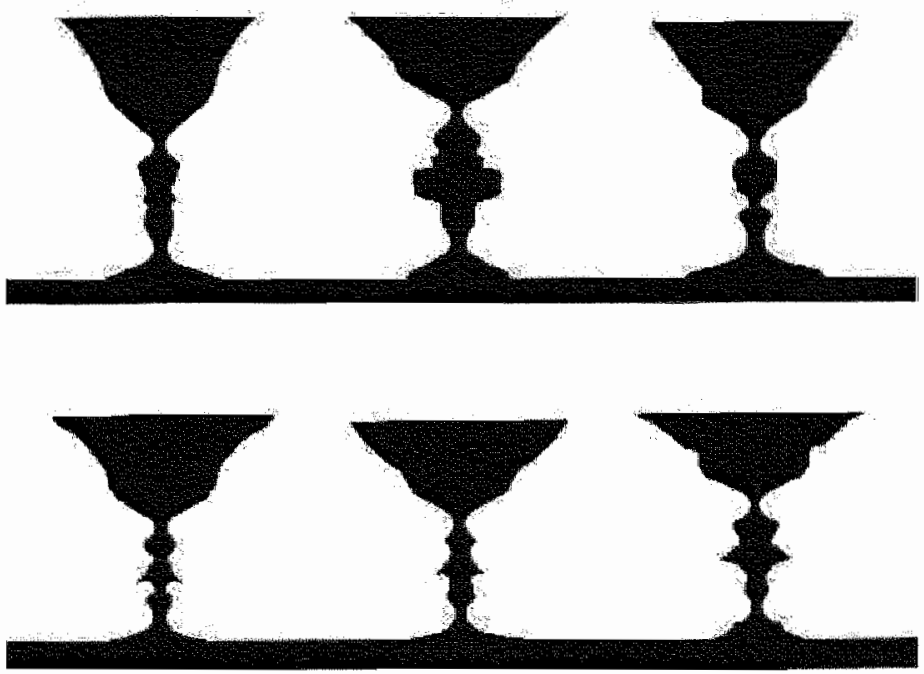

Figure 1 What do you see here?

Some of you, possibly the more cosmopolitan of you, see a set of six wine glasses. Others see twelve faces looking at each other. It doesn't matter which of the two you see, the important thing is that there is an absolute duality or dualism ${ }^{1}$ in this illustration that doesn't allow you to see the two different objects at the same time.

And now another picture. What do you see here? 


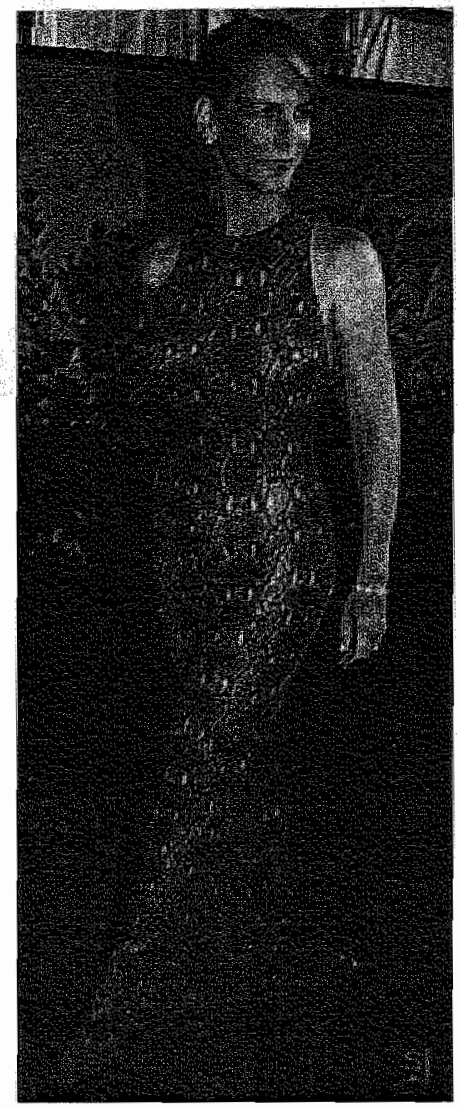

Figute 2 And what do you see here?

You're probably thinking: Has he gone completely mad? Some of you see Jamie Leigh Curtis, the actress who starred in such films as "A fish called Wanda". Others - the older of you - see traces of her father Tony Curtis and her mother Janet Leigh. And I'm willing to bet that all of you think that see you see a failly good looking woman, even if you don't know who she is. But those of you who thought the last are all technically wrongl $O K$, you're now sure of it; he has gone completely mad. But what's the case here? Jamie Leigh Curtis, the 'woman' pictured here, though phenotypically definitely a woman with two children is genotypically a man ${ }^{2}$. Yes, you heard me right. Here, within one person, there's an apparent unsolvable duality. 
But this isn't really that strange. Life is essentially a duality. Woman and man, day and night, wave and particle, learning and working. But in this duality it's not all black and white. Between the extremes are many shades of gray. Medical science has shown that between $X X$ and $X Y$, genetically speaking, there are a number of variants ${ }^{3}$ (Spaink, 1998). Between day and night there is dawn and dusk. In physics, electromagnetic radiation such as light, behaves in a dualist way ${ }^{4}$. And between learning and working there are many ways to combine the two.

But before I begin discussing the duality, or possibly better the mutuality of learning and working, l'd like to discuss the strange character of education which tends to cause it to be dual within itself. This inherent duality of education was well documented by me in my Ph.D. thesis (Kirschner, 1991) where I characterized the thinking in science education as something that tends to vacillate between two extremes as does a pendulum when it swings ${ }^{5}$.

\section{Duality in education}

The term 'dualism' was originally coined by Thomas Hyde around the beginning of the eighteenth century. As a metaphysical theory, dualism states that the world is made up of two elemental categories which are incommensurable. This includes distinctions between mind and body, good and evil, universal and particular, and phenomena and noumena. Dualism contends you must have both of the two components in question, rather than one or the other. A major problem faced by dualists, thus, is the inability to resolve the rift between the two opposing elements.

Science education has been a specific victim of this duality throughout it's short history, especially with respect to its use of laboratories. Early science education made absolutely no use of labs. It wasn't until 1824 in Germany and 1830 in Great Britain that laboratories became a part of the curriculum ${ }^{6}$. This practical work, however, was largely supportive and was used for confirming theory which had already been taught. There were no genuine experiments and if something went wrong it did not matter; the expected results were printed, along with details of the procedure, in the textbooks 
(Lock, 1988). Even worse, there were no specific rationale or rights of existence for labs at all. They were completely subservient to the lectures and texts.

At the end of the nineteenth century this changed. A more enlightened approach to science teaching, the heuristic movement, "sounded the death knell of the old object lesson" (Kerr, 1964, p. 10). This movement held that science was an affair of the laboratory and workshop rather than of the classroom. The heuristic method develops pupil initiative and teaches self-reliance, good judgement and manipulative skill, by personal contact with apparatus and material. By 1896, this "discovery approach" was adopted in and dominated the school science syliabus, but only lasted until $1918^{7}$ at which point universities reverted to traditional demonstration or cookbook type laboratories.

This remained the case until the late 1950's (as a result of the launch of the Sputnik ${ }^{8}$ ) when the pendulum swung again and the use of laboratories in science education was justified by alluding to the idea that experimentation is learning by doing. The epistemology of the scientist became the pedagogy of science teaching. There could be no substitute for this activity and, thus, experimentation was an essential part of good and responsible science education. Running through all of these curriculum reforms was the notion that science could not be taught in an authentic manner unless students were involved in 'worthwhile' experiments. Scientific curriculum committees tried to redefine the purposes of laboratories with the primary function being to convey the method and the spirit of scientific inquiry (Hurd, 1969).

Since these reforms there have again been an number of shifts back and forth with 'constructivist pedagogy' bringing us back to the idea of authentically situated learning environments for optimall learning.

\section{Pragmatism and educational design}

It has often been stated that the only contribution of the United States of America to the realm of philosophy is the notion of pragmatism $^{9}$ (Dewey, 1903). Dewey, the father of pragmatism, argued that the traditional correspondence theory of truth, according to which the true idea is one that agrees or corresponds to reality, only begs the question of what the "agreement" or "correspondence" of idea with reality is. He maintained that an idea agrees with reality, 
and is therefore true, if and only if it is successfully employed in human action in pursuit of human goals and interests, that is, if it leads to the resolution of a problematic situation.

He further argued, both in School and Society (1907) and Democracy and Education (1916), that education should not be viewed as merely a preparation for civil life, during which disjoint facts and ideas are conveyed by the teacher and memorized by the student only to be utilized later on. The school should rather be viewed as an extension of civil society and continuous with it, and the student should be encouraged to operate as a member of a community, actively pursuing his or her interests in cooperation with others. It is by a process of self-directed learning, guided by the cultural resources provided by teachers, that Dewey believed a person is best prepared for the demands of responsible membership within the democratic community. Knowledge is then acquired by "going over one's past experiences to see what they yield (p. 157)." In other words, it should not be assumed that knowledge is transferable as an automatic consequence of assigning meaning to an experience. Knowledge is relatively specific to the purposes for which it was acquired.

Also in Democracy and Education he remarked that in spite of the fact that teaching by pouring in and llearning by passive absorption are universally condemned, they are still entrenched in practice. Education was for him not an affair of "telling" and being told, but an active constructive process (as we see he was years ahead of his time) which unfortunately is as generally violated in practice as it is conceded in theory.

Applying this philosophy to education means that:

- education should be a preparation for life,

- solving problems is important - therefore real life situations should be used;

- teaching methods should be varied and flexible,

- education should be action oriented, and the

- needs and interests of the students must be considered

\section{Constructivism and educational design}

Constructivism, as is pragmatism, is neither an approach to nor a model for instructional design. It is a philosophy (of learning) based on the idea that knowledge is constructed by learners - and 
eventually "the one(s) who know(s) - based on their mental and social activity. Learners are active in seeking meaning. Consistent with this view, learning (not teaching!) must be situated in a rich context, reflective of real world contexts, for this constructive process to occur and for transfer to environments beyond the school to be possible.

Constructivism holds that in order to learn, learning needs to be situated in problem solving in real-life contexts where the environment is rich in information and where there are no right answers (embedded knowledge). The tasks must be authentic and are best learnt through cognitive apprenticeship on the part of the learner in a rich environment. Meaning is negotiated through interactions with others where multiple perspectives on reality exilst. Reflexivity is essential and must be nurtured. Finally, all of this is best (and possibly only) achieved when learning takes place in illstructured domains. Taking these one for one:

- Situated learning and authentic tasks: Situated learning (Brown, Collins \& Duguid, 1988) is a method of ensuring that students learn to understand concepts anchored within the context of an area of study. Instead of abstracting unrelated bits of knowledge in an area or culture of study, a student learns about a subject area by immersion in that culture. The objective is to produce a student who, if studying within a certain area or professional domain, understands how a practitioner within that domain acquires knowledge, finds information in his or her field and integrates this knowledge to solve problems in that domain. A rich context for problem solving becomes part of this component.

- Cognitive apprenticeship: In cognitive apprenticeship, a teacher models those thought processes that characterize an expert in a particular field (Collins, 1988). Achtenhagen (2000) refers to this as modeling the model. Experiences are provided for the student that mimic the apprenticeship programs of adults in trades, or teachers in internship. Although it is not possible to submerse the student to the extent that an internship would imply, through the use of simulations and meaningful experiences, the student would learn the ways of knowing of an expert.

- Social construction of shared perspectives - Collaborative learning: Von Glasersfeld (1988) discusses the social construction of knowledge where concepts are developed in a process of fine-tuning involving interaction of others. Group interaction aids this process, because it exposes the learner to 
multiple perspectives about a theme. Collaborative learning which emphasizes the need to examine an issue from all sides gives students the understanding of various points of view.

- Nurturing reflexivity: Constructivists believe it is important to encourage reflexivity whereby students become aware of how their own thinking processes work. Helping students to think about how they are arriving at conclusions, or how they go about solving problems, helps form more meaningful links between knowiedge and develops more elaborate cognitive schemata.

- Ill-structured problem domains: Spiro, Coulson, Feltovich \& Anderson (1988) developed the Cognitive Flexibility theory that addresses knowledge acquisition in ill-structured domains. It was developed after they discovered that many learning failures resulted from cognitive oversimplification and the inability to transfer knowledge and apply it to new cases. In many cases, the design of learning involved the use of typical cases to explain a concept. The solutions to these typical cases were usually too obvious for students, so many students could not solve problems that involved more complex sets of factors. To counter these problems they suggested the need for instructional systems which allow students to revisit "the same material, at different times, in rearranged contexts, for different purposes, and from different conceptual perspectives" (p. 28). The idea is that many crosslinks may occur, and conceptual richness will develop as a student spends time investigating the various connections between themes or concepts.

\section{Goal of education: Knowledge or competencies?}

This is all very well, but what is actually the goal of present-day higher education and is it achieving this goal? There is a growing concern in professional contexts about performance levels of new recruits and existing staff (Boyatzis, 1982; De Snoeck, 1997).

Graduates of universities have the knowledge necessary to do the job, but miss the "higher order skills" and attitudes necessary to do the job properly. Job descriptions are presented in terms of task profiles, human resource management is based on skills management approaches and literature on professional training clearly reflects this focus on job related 'competencies'.

In educational contexts there is a growing call for competencybased education; although the concept of competencies is not 
always used. Competencies can be construed as abilities that enable learners to recognize and define new problems in their domain of study and - future - work as well as solve these problems (Kirschner, van Vilsteren, Hummel, \& Wigman, 1997). According to Keen (1992), competencies refer to the ability to operate in ill-defined and everchanging environments, to deal with non-routine and abstract work processes, to handle decisions and responsibilities, to work in groups, to understand dynamic systems, and to operate within expanding geographical and time horizons. Jeroen van Merriënboer characterizes competencies as a combination of complex cognitive and higher-order skills, highly integrated knowledge structures, interpersonal and social skills, and attitudes and values. Acquired competencies enable learners to apply these skills and attitudes in a variety of situations (transfer) and over an unlimited time span (lifelong learning) (van Merriënboer, 1999).

In educational circles, educational designers are moving from cognitive, often rule based instructional design for efficient and effective teaching towards constructivist instructional design for competency based learning. The problem is that this is not a question of adaptation of the design methodology used, but is a question of beginning anew.

\section{The old way doesn't work anymore}

Traditionally, the paradigm for organizing curricula used by educational institutions is the teaching/learning paradigm. Curricula are subject-matter oriented and organized as such. They are divided into courses on specific areas of expertise, often the result of a combination of historical factors (This was the way I learnt it), an analysis of the - so-called - intrinsic or objective structure of a domain or discipline (This is the 'objective' hierarchy of the subject matter) and/or an analysis of the expertise of the teachers available (Professor $\mathrm{X}$ is an expert in ...). Learning, often not more than the acquisition of knowledge, is assessed through traditional assessment methods (knowledge tests, essay tests, individual term papers and theses, et cetera).

Curricula which are based upon a competency based paradigm are fundamentally different. They essentially require an educational institution to begin from scratch. These curricula are based upon a network of interrelated, often heterarchically organized competencies relating to what a professional can and must do. For example, most 
doctors can be seen as having four basic competencies, namely taking a case history (of all patients starting from a newborn baby up through a geriatric patient), diagnosing a problem (using state-of-theart tests, instruments and insights), determining a treatment (based upon the newest physiological, pharmacological and psychological insights) and evaluating the treatment (determining if the chosen treatment worked and if it could have worked better). These competencies subsume, in turn, intricately nested networks of knowledge, skills and attitudes that cannot and may not be pigeonholed into quasi-complete, independent courses. It is no longer a question of just-in-case learning (Here you have Anatomy 101, ranging from the brain to the bone in your little finger just in case you need it in the future), but rather of just-in-time learning (Here we have a problem with dealing with a specific problem or symptom and to solve it you need ...). Developing such a curriculum is further complicated by the social and attitudinal aspects of the profession. These knowledge, skills and attitudes also cannot be pigeon-holed into courses on ethics or bedside manner. They require learning settings in which the knowledge can be gained and the skills can be acquired in authentic, meaningful contexts, where the necessary interactions with others (either other members of a team or the 'problem-owner') are fundamental elements of the setting and where the student can (or is forced) to reflect upon what the or she has done and develop attitudes intrinsic to the profession. Finally, the assessment of this type of learning requires (specially) adapted assessment situations and procedures specific to assessing the attainment of the intended competencies. If a doctor needs to be competent in taking a case history of patients including scared five year olds, then he/she must be assessed in a way in which the assessor can determine of this has actually been achieved (authentic assessment).

This earthquake in thinking about education means that if we are going to transform our educational institutions towards competency based learning environments, then we must also approach the design, development, and implementation of such education in a way that the achievement and assessment of those competencies is made possible and is facilitated (effective, efficient and satisfying). The means a reengineering of the instructional design process. 


\section{Education at the Faculty of General Science}

The Faculty of General Sciences at Maastricht University makes use of Project Centered Learning (PCL) in its Knowledge Engineering program $^{10}$. PCL is aimed at activating students to learn both the content and the process of knowledge engineering by working in teams on a project to deliver a product within a well defined time span. The set up of the curriculum is an embodiment of the concept of situated learning. Students are placed in authentic learning situations in which they are expected to make use of the knowledge that they already have or the knowledge that they gain in their courses to work on projects that are similar to those that they will encounter upon graduation while working in their chosen profession. Not only are the projects 'authentic', but the work situation is also authentic. Students work in teams fulfilling the different roles that they would fulfill if they were actually in a working environment.

The projects presented and the classes taught are fine tuned to each other such that the content is necessary for carrying out the project and the project allows students to actively make use of the knowledge that they gain in a relevant and authentic situation. The projects are, in essence, the motor driving student learning. They are the vehicles that allow and stimulate students to:

- search: to orient themselves in a situation and to analyze it so that they can identify and represent the actual problem;

- solve: to gather and choose relevant information, synthesize and generate solutions, make a choice as to the best or most adequate solution;

- create: to actually create a product; and

- share: to actually communicate findings in the form of a report, a presentation, an article, and so forth.

In the first three years, the academic year is divided into four blocks of ten weeks each. The structure of a block is shown in figure 3 . 


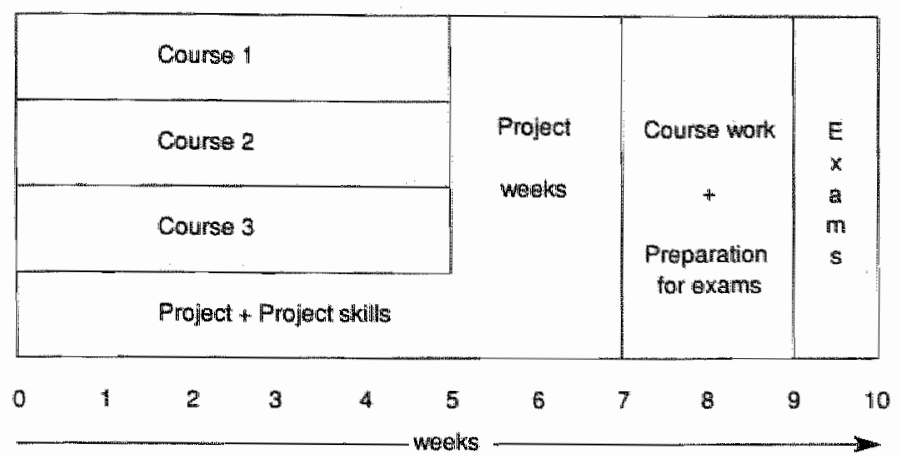

Figure 3 Structure of a block

At the beginning of a block, the emphasis is on the courses and their content. There are lectures, practicals and seminars/tutorials on the course conternt. The project also begins at the start of the block at which time the students, in teams of five or six, orient themselves to the project as well as to the knowledge, the techniques, and the methodology necessary to carry it out. The project confronts the students with complex problems which are representative of what they will encounter upon graduation. The students also receive a parallel training in project skills such as organizing and planning a project, working in teams, reporting and presenting their conclusions, interviewing, writing an academic paper with the help of specific tools such as LaTeX, and so further. After this first phase which lasts five weeks, students work further in their teams on their projects for two full weeks at whose conclusion a presentation - accompanied by a report on the project - is made for the whole year cohort and where a grade is given. After this there are two course weeks in which the content is further worked out and use is made of what the students learned and experienced in the projects. The black is concluded with one examination per course.

The projects in the freshman year come from within the university; the projects in the sophomore and junior years are defined by external clients. The final responsibility in both cases is in the hands of the faculty. 
An interesting note here is that a number of sophomores carry this project work within teams to the extreme by starting their own real life companies to carry out the same types of projects that they have learnt to carry out in their education here. Apparently this form of education effectively orients the students within their chosen profession; one of the major goals of the freshman propaedeutic year.

\section{Cooperative education as embodiment of both duality and constructivism}

Chickering (1969) states that the purpose of higher education is not merely the acquisition of knowledge. In addition to this cognitive dimension, students also need to learn across behavioral and affective dimensions. A key point here is that students need to be able to acquire behavioral and affective knowledge and integrate it with their classroom-acquired cognitive knowledge to become successful graduates ${ }^{11}$. In other words, creating a learning environment for students based upon constructivist philosophy has the ability to fill the gaps in traditional higher education.

Acquiring certain types of knowledge depends upon previously acquired knowledge and the stimuli offered by the context. As a result, the order in which educational elements are processed, the composition of the curriculum as a whole and the distribution of competence acquisition across educational and professional life determine the effectiveness. The question that then arises is: Should learners acquire deep knowledge in a domain in order to transfer it to a different (working) context or should competence development be aimed at the simultaneous development in a wide field of knowledge or should traineeships be carried out as early as possible (even to the extent of a constant intertwining of practice and theory) so that knowledge can be acquired against a context of contextual experience? (Heijke \& Nijhof, 1998).

Jef Staes, Education Manager at Siemens-Atea in Belgium, who looks at this problem from a more business and human resource management perspective states it in a different way (Staes, 2000). He notes that real learning takes place primarily when information 
necessary for competence acquisition and development is actively sought by the one who needs it. He calls this "pull learning" .

In order to achieve pull learning, the learner must be put in the right role. Only if this is the case can knowledge management start and only then can creativity and innovation begin. Although Staes is convinced that changing people is as easy as changing the weather, he is also convinced that effective and efficient environments can be created for increasing the learning power of students and their rate of learning. In his first law he states that:

$$
L P=L T \times I F
$$

Learning Power = Learning Tension multiplied by Information Flow

Learning Tension is a physical tension on the brain. The higher it is, the more one hungers for information. People in the right role develop a high learning tension. If students are placed in the right rolle, and they have the personal goals and capabilities to reach them, then they will have a high learning tension and their learning behavior will be markedly different from that of the average student.

Thus, if we can create a learning situation where the Learning Tension increases, then the Learning Power of this environment and the students within it will also increase. Ceteris paribus, in a learning environment where the Learning Tension approaches zero, the Learning Power will do the same.

Wendy Smits (in Heijke \& Nijhof, 1998) a researcher at the Research Centre for Education and the Labour Market at this university tends to bear this out in her analysis of the combination of working and classroom learning in an integrated setting. She has shown that the combination of working and learning has a positive effect - both economic and educational - on the development and use of competencies.

There are a number of well known and often used vehicles to achieve this. Typical examples are the creation of collaborative and cooperative learning environments in classroom and distributed settings (Computer Supported Collaborative Learning), traineeships, internships of differing lengths, et cetera. The ideal embodiment of the pedagogic idea of combining learning and working as well as the application of constructivist philosophy to education (especially the 
ideas of cognitive apprenticeship and nurturing reflexivity) can better be found in cooperative education ${ }^{12}$.

\section{What is cooperative education?}

The National Commission for Cooperative Education in the United States defines cooperative education as "a structured educational strategy integrating classroom studies with learning through productive work experiences in a field related to a student's academic or career goals. It provides progressive experiences in integrating theory and practice. Co-op is a partnership among students, educational institutions and employers, with specified responsibilities for each party" (National Commission for Cooperative Education, 2000).

Cooperative education is characterized by a unique combination of learning and working where the work is paid for (the student has a contract and is thus an employee with rights and responsibilities) and where the work is an essential part of the academic curriculum with respect to both academic learning and academic development. In this trilateral collaboration, there are also contracts between the university and the student dealing with the rights and responsibilities are of these two parties with respect to the education of the student and between the university and the employer with respect to tutoring by the employers, assistance by the university, non-disclosure, and so further.

Cooperative education has its practical and educational roots in engineering curricula in the United States in 1906. Herman Schneider, a professor of engineering at Lehigh University, first proposed this form of education based upon two observations as a teacher. First, most college students that he encountered worked part-time, while that work had no relationship to either their field of study or their future prolession. Second, he noted that there was a number of elements in the teaching (and learning) of engineering that could not be conveyed properly in the classroom or in the laboratory. To solve these two anomalies he proposed putting students into paid engineering positions so that they could work at their future profession while learning it (learning while doing).

Cooperative education has its philosophical roots in its particular expression of educational pragmatism that I discussed earlier. In 
accordance with Dewey's belief that education is not an end in itself; but rather a means to help prepare students for effective and satisfying citizenship, it is a form of education which is grounded in experience. Institution, teachers, mentors, supervisors and students build the intimate and necessary relation between the process of actual experience and education which prevails in an environment where reflective practice ensures that the learners learn from experience by taking responsibility for it (Van Gyn, 1996).

In other words, cooperative education is paid participation of the student in long trajectories within the work force in their chosen field with as goal the attainment of cognitive, affective and behavioral competencies.

In the Netherlands some of this legacy is seen as normal. Both the medical and the nursing professions have long made use of this manor of education (although the students are not always paid). Teaching colleges and universities are, since 1997, making use of teachers-in-training whereby students function as paid teachers in their fourth year of study (as opposed to internships where they receive no financial remuneration and where they are coached by their mentor within the teacher's college).

Cooperative education as educational philosophy and pedagogy is catching on quickly in professional higher education. Here there are three major systems of cooperative education namely the Gilde, the Co-op, and the MKB-route variants. Each of the variants departs from the premise that students put their academic knowledge into action through relevant work experience outside the classroom and then bring the challenges and insights they gain on the job back to the class for further analysis and reflection.

The Gilde variant (literally craftsman's guild system variant) goes the farthest. Students are placed in paid positions from the beginning of their studies where the ratio of workplace/school bank is roughly $60 / 40$. The Co-op variant starts students in the workplace after they have completed one year of traditional education. Beginning in the second year, students spend one semester in the workplace and one semester in the school. Finally the MKB-route (English: SME-route) variant. first has its students complete two years of traditional study. These students are then placed in "more advanced" work positions within small and medium sized enterprises.

In the academic year 1998/1999 five thousand students were registered as cooperative students in 137 different trajectories (a 
$400 \%$ increase in students above the previous year). In September 1999 there were 350 registered cooperative trajectories; an increase of more than $250 \%$. At this moment there are also 28 cooperative education experiments at the university level.

\section{Are there proven benefits for this type of education?}

Both theoreticians (Deighton, 1971; Stadt \& Gooch, 1977) as well as empiricists (Cash, 1987; Petrysak \& Toby, 1989; Rowe, 1989; Branton et al, 1991; Van Gyn, Cutt, Loken, \& Ricks, 1997) have shown that there are definite benefits for this type of education. The most stated benefit is that students are more motivated to study and learn. Schank (1995) attributes this to not just to simply motivating learners to want to learn something, but rather to the awakening of internally generated motivation arising from knowledge goals and not externally generated (e.g., grades). In order to acquire that knowledge the learner must understand the need for that knowledge at the time of its appearance. In other words, explicit awareness of one's knowledge goals is key to the acquisition of explicit knowledge.

Other well documented benefits are that there is an increase in student communication and human relations skills, that students $I$ graduates function better in social institutions, that students acquire more skills with respect to performing complex tasks (as compared to students in traditional curricula), that they are better able to solve problems, that they better acquire and retain theory and facts due to the relevancy of the learning situation and finally, there is an improved job placement and work satisfaction after completion ${ }^{13}$. The proven increase in learning observed is even more pronounced for cooperative students in the lower half of the class!

Along with these more cognitive benefits, cooperative students and graduates also benefit with respect to their career development. Students are both clearer and more confident with respect to their career goals have a better idea of / orientation towards the labor market and their future profession and feel more prepared for carrying out their chosen work.

\section{And are these benefits also accruable within the natural and technical sciences?}

The American Society for Engineering Education, the Accreditation Board for Education and Technology (ABET), and the Engineering Dean's Councill in their Joint Task Force on Engineering Assessment 
(1996) articulated the need to inter-relate education and practice. In their view, the education provided in engineering programs accounts for less than half of the education that the marketplace needs from entry-level engineers and a "simple make-over of traditional course work and laboratories alone" cannot alleviate the problem.

The ABET's Engineering Criteria 2000 (1995) defines eleven abilities that graduates from an engineering program must demonstrate. Four of them are easily learnt within the traditional setting, namely:

- an ability to apply knowledge of mathematics, science, and engineering;

- ability to design and conduct experiments, as well as to analyze and interpret data;

- an ability to design a system, component, or process to meet desired needs; and

- an ability to identify, formulate, and solve engineering problems.

Seven abilities, however, cannot be properly addressed in the traditional setting, namely:

- an ability to function on multi-disciplinary teams;

- an understanding of professional and ethical responsibility;

- an ability to communicate effectively;

- the broad education necessary to understand the impact of engineering solutions in a global and societal context;

- a recognition of the need for, and an ability to engage in life-long learning.;

- a knowledge of contemporary issues.; and

- an ability to use the techniques, skills, and modern engineering tools necessary for engineering practice

In their view, cooperative education is a strategy that promotes learning within engineering students in ways that enthance traditional course work and laboratories. This results in students being fulty prepared to enter the engineering protession upon graduation, with skills, attitudes and behaviors that are critical to the market place, be it academic or commercial.

\section{Finally, why should a company agree to this?}

in a very recent article, Smits (2000) notes that tirms have different reasons to employ apprentices. She notes that the economic 
literature usually makes a distinction between current production considerations and a future need for qualified labor. In the first case the main reason is the contribution to the production process (the substitution of cheap apprentices for expensive skilled labor). In the second case it is to fill a need for qualified workers. In practice both play a role (to a certain extent). The apprentices' contribution to the production process allows the firm to recover part of the training costs and makes it worthwhile even if there is a risk that the trainees will leave the firm after completing the training.

Browne (1987) reports that according to employers the costs of participating in a cooperative education program are marginal and whatever costs are incurred, they do not weigh up against the clear productivity of the students who - in their eyes - more than earn their own way ${ }^{14}$. This is in addition to their perception that cooperative education students have more and better technical knowledge, have better communication skills, cooperate better with their fellow workers and are more motivated than non-cooperative education students.

Finally, cooperative education gives the employer a pool of new talent to choose from upon their graduation. The employer knows the graduates, knows their qualities an thus takes less of a gamble when hiring them. Studies show 'rehiring' percentages of approximately $40 \%$ (approximately $60 \%$ are offered jobs) with a retention rate sometimes approaching 80\% (Browne, 1987).

\section{The future}

On June 19, 1999 the European Ministers of Education issued a joint declaration at a meeting in Bologna. This has become known as the Bologna Declaration. In this declaration the ministers attempt to clear the way for greater compatibility and comparability of the different systems of higher education in Europe.

To achieve compatibility, the ministers agreed to the adoption of a system of credits - a European Credit Transfer System - to help promote student mobility between institutions and to create a system of "easilly readable and comparable degrees ... through the implementation of a Diploma Supplement".

To try to achieve comparability they agreed to adopt a "system based essentially on two cycles, undergraduate and graduate. Access to the second cycle [requires] successful completion of the first cycle studies, lasting a minimum of three years. The degree 
awarded after the first cycle shall also be relevant to the European labour market at an appropriate level of qualification. The second cycle should lead to the master and/or doctorate degree ...."

This system has been hastily christened, in imitation of the American and British systems of higher education, the bachelor master system and in the hallowed halls of professional and academic higher education has been given a length of study of $3+2$ years respectively ${ }^{15}$.

Although some question the legality of the declaration itself, it has proven to be a stimulus for higher education to re-evaluate itself and the diplomas it awards and the curricula taught. It has given higher education pause to re-examine itself as well as to re-examine the purported distinctions between the different types of higher educational institutions. The Declaration itself doesn't differentiate between polytechnic professional education and academic university education. Both may award bachelor and master diplomas. The Bologna Declaration has effectively placed this discussion on the political as well as the educational agenda (Staa, 1999).

Maastricht University is also busy in this way. There is presently a working group ${ }^{16}$ headed by Hans Philipsen which is busy designing and evaluating a number of possible scenarios to determine what the best route would be for the university. Parallel with this, most of the faculties within the university are also busy with this (self) reflective process. Within the Faculty of General Sciences this discussion on bachelor-master could prove to be the motor for one of the most important and well-founded educational innovations in university education since Maastricht University chose for problem based learning almost twenty five years ago ${ }^{17}$.

\section{My view}

In my perspective the future of education at the Faculty of General Sciences must combine the best of three worlds, namely $\mathrm{PCL}$; cooperative education and the bachelor-master structure of education.

The global set-up of the faculty should be a five year curricullum which would ultimately grant the student a Master diploma. The first three years would be the Bachelor phase. 
With respect to the goals, this phase aims at least four major areas of competence (derived partly from Schuyt, 1998). First, it would produce graduates with a broad range of intellectual competencies and skills. Our graduates must be capable of solving problems, working with others, studying and working independently, where necessary finding and making use of relevant source materials, creatively producing ideas to allow the thought and work process to function better, helping colleagues, planning their work, and so further. All of these competencies and skills are rooted in a primary domain of knowledge which is there chosen field of study. Second, our graduates will have a high level of knowledge and skills within their chosen field of study. Graduates have a large amount of ready knowledge in their field, but are also uniquely aware of what they do not know and what they need to learn. Third, they are intellectually independent and self-reliant with respect their field of study. They have gained the attitude necessary to be successful in their chosen field or future study or profession. This includes the skepticism necessary to practice science and the will to discover and learn more. Finally, our graduates have knowledge and skills in another area other than their major field of study. Often this will be in a field of application of their study, but this need not be the case. These four goals are not that different from the core curriculum at Harvard which "rests on the conviction that every Hanvard graduate should be broadly educated as well as well trained in a particular academic specialty or concentration....[the] knowledge, intellectual skills, and habits of thought that are the hallmarks of educated men and women".

With respect to content, this phase should be characterized as a package of related courses forming a complete whole, both in the judicial sense of being recognized as a degree as in the civil sense such that the graduate is a qualified professional who can think and function at an academic level within a professional work situation. This is the first criterion that distinguishes this academic Bachelor's degree from a professional Bachelor's degree. The nature and content of the courses making up the curriculum are dependent upon the nature of the program. If we are talking about a Knowledge Engineering program the focus would be exact and the content would rely heavily upon the two already existing and imminently qualified departments of mathematics and computer science or informatics. It would, however, be advisable to allow the students a certain amount of freedom in the direction of electives or a minor to 
study outside of the two basic disciplines (see the prior paragraph). It would be quite different if the faculty chose to broaden its ken and to be the first Dutch university to deliver a truly new Information and Communication Technology (ICT) program. Such a program naturally has a strong basis in mathematics and computer sciences, but also will need a large part of the program to concentrate on the practical (e.g., legal and economic), psychological, and societal (e.g., moral, cultural and ethical) implications of IGT developments. Finally, in accordance with the mission of the university itself, there would be an accent on the international aspect of Knowledge Engineering and ICT. This means that study in another country and the mastering of a second language is imperative and thus required within the Bachelor phase. Partnerships with other institutions is needed, but this is also simplified if the goals of the Bologna Declaration are achieved.

With respect to the educational approach, this phase would be project centered as the program now is, but with a stronger accent on the integration of the supporting disciplines. The courses given and the order in which they are given in the present Knowledge Engineering curriculum strongly determine the character of the projects that thew students must carry out. This idea is based on the earlier stated premise that there is a natural, objective and logical order within a subject area. Though this may be the case for a small number of topics or disciplines (mathematics might qualify here), this is definitely not the case for a complete discipline. In the new Bachelor curriculum, the nature of the competencies - and not the nature of the disciplines - would determine the character and sequence of the projects and the chosen projects would in turn determine the character and content of the courses provided. Another difference would be the relative weight of the projects within the curriculum. Although the projects and the project skills are examined and the grades received determine whether a block is successtully completed, they do not play a role in the final grade for the students. In a new curriculum the project and the project skills need to carry a weight comparable to the more knowledge based examinations of the disciplines with the idea, in the back of our minds, remembering that if we are talking about a real competency based curriculum, then the proof of the pudding should be in the eating and thus the certification of the achievement of a competency should be in the evaluation of the student's ability to display its total achievement and not only regurgitating or applying its component knowledge. Finally, the conclusion of the Bachellor phase would 
encompass the carrying out of a large project within a company or within the university (I will come back to this point soon). This project would be, minimally, one trimester long and would be both a certification requirement for receiving the Bachelor's title as well as the entrance requirement for all those wishing to follow a Master study at the faculty.

This idea, along with the idea of cooperative continuing of the education, is supported by $H$. van den Bosch (2000) who, in an article on implementing bachelor-master education, makes a strong case for the enrichment of the study through work experience. He makes a strong case for this arguing that "it can be a revelation and even beneficial for the student to experience high quality work during the study" (p. 9).

This project centered Bachelor phase is followed by a two year $100 \%$ cooperative Master phase. In this phase "traditional" or initial students orient themselves for a short period to different working situations so that they can follow this up by actually participating in a work-study program. This work study program can take place in one place of employment (for those students who are sure of their ultimate direction) or may be divided over two places of employment for those students who are still uncertain. This presents three unique situations and possibilities.

The first possibility is the chance to carry out academic scouting at the university. Although most people will envision this cooperative phase as taking place in a commercial situation, this need not be the case. On January $27^{\text {th }}$ of this year our vice-chancellor, Prof. dr. Nieuwenhuijzen Kruseman, spoke to us on the occasion of the $24^{\text {th }}$ anniversary of the founding of this university. In his speech entitled "Science is still people work" (Nieuwenhuijzen Kruseman, 2000), he made a strong argument for scouting promising talent within the academic world to ensure that the academic community is supplied with high quality fresh blood. To quote him directly, "Per year 3000 students stream through the portals of this university. One half of one percent of this stream necessary for maintaining the scientific infrastructure of the university. It shouldn't be too difficult to track down these pearls for the scientific community in the initial phase of their university education in a university whose two dominant profile characteristics are its small scale and its devotion to student oriented education." (p. 33). This cooperative Master trajectory could provide 
exactly the situation needed to allow the scouting and contracting of this much needed talent.

The second possibility is the chance to increase both our student base as well as our revenues by providing a unique situation for businesses. Many businesses within the ICT world have a large population of workers from professional colleges or polytechnics. Both the workers and the companies would profit if these workers were provided the opportunity to update, but more importantly upgrade their level of knowledge and thinking within projects that are also relevant for the companies and which are under the guidance of high quality academic staff from a university. It is human resource management, corporate education and consultancy all rolled into one! These companies are willing to invest in their human capital because they know that this is also profitable for them. If we create the conditions, with respect to the logistics, the administration and the infrastructure (in terms of ICT) for teaching, coaching and working with our initial students working on their Master degrees in companies, then we will also have met the conditions needed to teach, coach and work with these recurring Master's students already in the work force. One might even argue that this form of cooperative Master education could and should be the first form to be developed, even before the development of the project centered Bachelor.

The final possibility is the chance to achieve the already outlined benefits of cooperative higher education for all those students who choose to follow this course of study. If and when the word gets out that you can work and study and get a better education at our faculty in Maastricht the major problem will be how to deal with so many students. The solutions found for teaching and learning at a distance will help to ease the pain.

This all may not be as strange as it sounds. The former minister of Education, Culture and Science J. Ritzen appeared to believe in cooperative university education and summed up seven benefits of this form of education in relation to the student, the institution and business (Ministerie van Onderwijs, Cultuur \& Wetenschappen, $\left.1998^{18}\right)$. In his words, students profit because (1) the interaction between learning and working ensures a flexible transition from the school bank to the job market for them, because (2) they come to better understand the work situation and the relationship between what is learnt and what is needed and (3) they come to appreciate 
that learning past the initial phase of education is of the utmost importance and that continuing education is both necessary and normal.

Institutions profit because (4) intensive contact with business ensures a direct feedback from those businesses to the institution which leads to a permanent quality control of the curricula as well as its improvement and because (5) intensive contact with businesses gives them extra chances for giving courses, advising businesses and for doing practical research.

Businesses profit because (6) employers are presented with young potential workers as trainees and because (7) recruitment costs are reduced and security about the quality of recruits are raised.

\section{What are now the major problems in implementing this?}

First there is the need for the definition of this form of education as part of the didactic foundation of the institute. Successfully establishing a quality cooperative education program is a complex process. It requires no less attention than any other major change within the institution, and possibly more since it often contradicts the standard operating procedure (of both the administration of the institution and the 'educational history' of the staff). Institutional indecision and inertia delays any kind of change by a combination of ambivalence (where staff and students) don't know what is expected of them and endless committee discussion and debate ensues.

Second, it is necessary to break through the stubborn misconception that cooperative education is not academic (enough). Faculty members often perceive an "either-or" chasm between academics and work-integrated learning. The latter is frequently viewed as "vocational" instead of "academic" (National Commission for Cooperative Education, 2000). Ryder (1987) and Heinemann et al (1988) observe that cooperative education is considered by many traditional decision makers as 'academically tainted' and that "teaching faculty do not recognize that learning, thinking, and general professional development can be achieved using the work environment as a 'classroom' with the work itself serving as an instructional vehicle" (p. 113). In a ministerial report on cooperative higher education in the Netherlands (Beerends, Blees-Booij, van der Boom, \& Krooneman, 1999) university respondents exhibited the 
fear that cooperative education is dangerous for the academic level of the university and that the influence of the business community is tantamount to "selling your soul to the devil".

Woolridge (1987) sums it up as follows. Faculty usually resist cooperative education. It takes place outside of the professor's

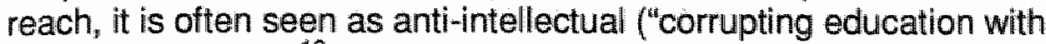
the realities of life" $)^{19}$ and it interrupts the status quo. Actually the opposite is the case. The student in cooperative education is a cognitive apprentice that has two experts which he/she can model. One is the teacher at the university whose academic attitude can be seen and emullated. Because the teacher is also involved in the problems of the workplace students see how the teacher's academic thought processes and vast knowledge are applied in an academic way to the problems and projects at hand. The other is the mentor at work. Students learn how the expert works in his or her field and what social and economic forces come to bear on his or her intellectual behavior. They are assimilated into the work climate and culture of the job situation. By broadening the learning situation to include reflection (in accordance with the ideas of Dewey) learners are stimulated to analyze how their two models function, to compare these to their own way of working and to develop their own style of working (Bolhuis \& Simons, 1999).

Thirdly, the cooperative education methodology for promoting learning needs to be researched and developed. Maastricht University prides itself with the fact that it is a national, if not international leader in educational innovation through its emphasis on small scale student centered education (primarily $\mathrm{PBL}$ ) and its international perspective, especially with respect to its programs and the nature of its academic and social life ${ }^{20}$. As an institution it has chosen to be on the forefront of educational innovation and to approach it, not from a cosmetic, but rather from a substantial point of view. An example of this was its willingness to take part in a transnational faculty of Knowledge Engineering with the Limburg University Center in Diepenbeek, Belgium and again in it's leading position in the formation of a Transnational University Limburg with that same institution. Supported by this legacy of educational innovation I| have confidence that the present project in cooperative education at the Faculty of General Sciences along with a recent memo of mine on durability and the future of PCL will lay the 
foundation for achieving a strong educational methodology for cooperative education ${ }^{21}$.

Finally information for both students and supervisors is of the utmost importance. Students that embark on this road to education need to have a good view of what the institution is and what it brings to their learning situation. What are they required to do, how can they rely on the institution, who is responsible for what and who is there to help when things threaten to go wrong. Students also need to have a good and realistic preview of the job that will form the other component of their education. The more the students know about the jobs that they take on and the more realistic their expectations the higher the quality of their cooperative education experience (Laycock, Vielhaber Hermon, \& Laetz, 1992) ${ }^{22}$.

\section{In conclusion}

To paraphrase Simone de Beauvoir in The second sex (1994):

Between learners and what is learnt education is reflective. There is no struggle, no victory, no defeat; in exact reciprocity each is at once subject and object, master and apprentice; duality becomes mutuality ${ }^{23}$. 


\section{Acknowledgements}

I've now arrived at the end of my address, where I get to thank people. For many it may be obligatory, but not for me.

First I would like to thank the members of the Board of Governors of Maastricht University for their faith in me from the first conversation that we had.

Then there is my ex-boss, colleague and friend Hans van der Linden who was one of the most important reasons why I came to Limburg. Hans, you inspired me - both professionally and philosophically - and you pulled me out of the sometimes deep dips that I managed to get into. And above all, you always believed in me even when I didn't believe in myself. Thank you Hans.

I would especially like to thank the Dean of the Faculty of General Sciences Prof. dr. ir. Kasper Boon for his vision, his perseverance, his vision, his support and his inspiration.

My colleague professors at the Faculty of General Sciences Jaap, Koos, Jan and Maaike: Thank you for your open acceptance of me from the very beginning.

My other colleagues at the university in the three different departments where I work. Thanks for making me feel at home.

Dad and Mom. Dad, you always had this - in my eyes - idealistic idea about what and who I was and could do. This stems from your incredible love of and belief in me, although you're always a bit impatient as to when I would jump across the next hurdle. It's now happened. Thanks dad. And mom. You were disappointed that I did not become a "real" doctor, and passed away shortly before I became a different kind of doctor. Now you cannot see that I surpassed your wildest dreams. Thanks for the push mom and tell Eddie that I did it.

Femke, Jesse, Mara and Aron who probably are more proud of me than I am of myself. Thank you for accepting the fact that I'm sometimes absent (either in mind or body or both), and for always making it more than apparent what's really important in life and why I do what I do.

And last, but definitely not least Katrien. Words cannot express my love and gratitude so I won't even try. Thank you for being you.

I have spoken. 


\section{References}

Accreditation Board for Engineering and Technology (1995). Engineering Criteria 2000. http://www.engr.uky.edu/ce/abet.html

Achtenhagen, F. (2000). Criteria for the development of complex teaching-fearning environments. Manuscript submitted for publication in Instructional Science.

Beauvoir, S. de (1994). Le deuxième sexe [The second sex]. London: Bloomsbury Publishing Plc.

Beerends, H. M., Blees-Booij, A., van der Boom, E. F. C.. \& Krooneman, P. J. (1999). Duale leerwegen: Evaluatieonderzoek HBO en een inventarisatie van de behoeften en wensen van (potentiele) 'duale werkgevers' in het gehele hoger onderwijs [Cooperative education: Evaluation study and inventarization of the wishes and needs of (potential) 'cooperative employers' in all higher education] (Beleidsgerichte studies Hoger onderwijs en Wetenschappelijk onderzoek 65). The Hague: Ministry of Education, Culture and Sciences.

Bolhuis, S. M., \& Simons, P. R. J. (1999). Leren en werken [Learning and working]. In J.W.M. Kessels \& C.A. Smits (Series Eds.) Opleiden en leren. Deventer: Kluwer.

Boyatzis, R. E. (1982). The competent manager. A model for effective performance. New York: John Wiley \& Sons.

Branton, G., Cutt, J., Loken, M., Ney, T., Ricks, F. \& Van Gyn, G. H. (1991). Educational benefits of cooperative education. Proceedings of the Seventh World Conference on Cooperative Education, Hong Kong, August.

Brown, J. S., Collins, A., \& Duguid, P. (1989). Situated Cognition and the culture of learning. Educational Researcher, 18(1), 32-42.

Browne, S. J. (1987). The impact of cooperative education on employers and graduates. In K.G. Ryder and J.W. Wilson (Eds.) Cooperative education in a new era (pp. 285-303). San Francisco: Jossey-Bass.

Cash, S. H. (1987). Employability and job satisfaction of co-op versus non-co-op business graduates. Proceedings of the Fifth World Conference on Cooperative Education, Amsterdam. September 21-25, 74-77. Bass.

Chickering, A. (1969). Education and identity. San Francisco: Jossey-

Collins, A. (1988). Cognitive apprenticeship and instructional technology (Technical Report No. 6899). BBN Labs Inc., Cambridge, MA.

De Snoeck, J. (1997). Zoeken naar de receptuur: competentiemanagement [Searching for a recipe: Competency manager]. In N.V. Bekaert (Ed.). Gids voor Personeelsmanagement, 76(11), 40-45.

Deighton, L. C. (Ed.) (1971). The encyclopedia of education (Vol. 2, pp. 438-444). New York: MacMillan. 
Dewey, J. (1903). Studies in Logical Theory. Chicago: University of Chicago Press.

Dewey, J. (1916). Democracy and education: An introduction to the philosophy of education. New York: Macmillan. Press.

Dewey, J. (1907). School and society. Chicago: University of Chicago

Heijke, J. A. M., \& Nijhof, W. J. (1998). The production of human capital and the position on the labour market. Maastricht, The Netherlands: Maastricht University. Research Centre for Education and the Labour Market.

Heinemann, H., Enright, J., Johnson, P., Murtaugh, K., Reed, G., Robinson, V., \& Wilson, J. (1988). Cooperative education and the academy: Ad hoc committee on cooperative education and the curriculum. Journal of Cooperative Education, 24(2-3), 109-119.

Hurd, P. D. (1969). New directions in teaching secondary school science. Chicago: Rand McNally \& Company.

Joint Task Force on Engineering Education Assessment of the American Society for Engineering Education (1996). A framework for the assessment of engineering education. http://www. asee.org/pubs/html/assessment.htm

Johnson, D. W., Johnson, R. T., \& Smith, K. A. (1991). Cooperative learning: Increasing college faculty instructional productivity. ASHE-ERIC Report on Higher Education. Washington, DC: The George Washington University.

Keen, K. (1992). Competence: What is it and how can it be developed? In J. Lowyck, P. de Potter, \& J. Elen (Eds.), Instructional design: implementation issues (pp. 111-122). Brussels, Belgium: IBM International Education Center.

Kerr, J. F. (1964). Practical work in school science. Leicester: Leicester University Press.Lock Utrecht.

Kirschner, P. A. (1991). Practicals in higher science education. Lemma:

Kirschner, P. A., van Vilsteren, P., Hummel, H., \& Wigman, M. (1997). A study environment for acquiring academic and professional competence, Studies of Higher Education, 2.2(2), 151-171.

Laycock, A. B., Vielhaber Hermon, M., \& Laetz, V. (1992). Cooperative education: Key factors related to a quality experience. Journal of Cooperative Education, 27(3), 36-46.

Ministerie van Onderwijs, Cultuur \& Wetenschappen (1998). OntwerpHoger Onderwijs en Onderzoek Plan 1998 [Draft Higher Education and Research Plan]. Den Haag: SDU. 
National Commission for Cooperative Education (2000). The cooperative education model. http:/www.co-op.edu/model.html

Nieuwenhuijzen Kruseman, A. C. (2000). Wetenschap blijtt mensenwerk [Science remailns people work]. Rede gehouden tijdens de $24^{\natural}$ Dies Natalis op 7 janulari 2000. Maastricht, The Netherlands: Universiteit Maastricht.

Petrysak, N., \& Toby, A. (1989) A comparative analysis of cooperative oducation and non-cooperative education graduates at Simon Fraser University. Unpublished paper, Simon Fraser University, Vancouver, Canada.

Rowe, P. M. (1989). Entry differences between students in cooperative and regular programs. Journal of Cooperative Education, 26, 16-25

Fyder, K. G. (1987). Social and educational roots. In K.G. Fyder and J.W. Wilson (Eds.) Cooperative education in a new era (pp. 1-12). San Francisco: Jossey-Bass.

Schank, R. C. (1995). What we learn when we learn by doing. (Technical Report No. 60). Northwestern University, Institute for Learning Sciences.

Schuyt, C. J. M. (1998). Op academisch niveau: Scholing en vorming in een gedifferentieerd stelsel van hoger en wetenschappelijk onderwijs [At an academic level: Education and training in a differentiated system of higher and scientific education]. Katholieke Universiteit Nijmegen.

Smits, W. (2000). The quality of apprenticeship training: Some empirical results for the Netherlands. Paper for the European Association of Labour Economists (EALE) Conference, Milan, Italy, June 22-25.

Spaink, K. (1998) $\mathrm{m} / \mathrm{v}^{\text {*: }}$ doorhalen wat niet van toepassing is $\left[\mathrm{m} / \mathrm{f}^{\text {*t* }}\right.$. strike out whichever is not applicable]. Amsterdam: Nijgh \& Van Ditmar.

Spiro, R. J., Coulson, R. L., Feltovich, P. J., \& Anderson, D. K. (1988). Cognitive flexibility theory: Advanced knowledge acquisition in ill-structured domains (Tech. Rep. No. 441). Champaign, IL: University of llinois, Center for the study of reading.

Stadt, R. W. \& Gooch, B. G. (1977). Cooperative education: Vocational, occupational, career. Indianapolis: Bobbs-Merrill Educational Publishing.

Staes, J. (2000). Putting the engine of innovation to work. http://knowinc.com/jefstaes/hso1.htm

Van den Bosch, H. (2000). Invoeren Angelsaksische model: Kansen benutten en risico's vermijden [Implementing the Angla-Saxon model: Exploiting chances and en avoiding risks]. TH\&MA, 7(2), 4-10.

Van Gyn, G. H. (1996). Reflective practice: The needs of professions and the promise of cooperative education. Joumal of Cooperative Education, $31(2-3), 103-131$. 
Van Gyn, G. H., Cutt, J., Loken, M., \& Ricks, F. (1997). Investigating the educational benefits of cooperative education: A longitudinal study. vournal of Cooperative Education, 32(2), 70-85.

Van Staa, A. (1999). De Bologna-verklaring: nieuwe labels of een Angelsaksische onderwijsopzet in Nederland? [The Bologna Declaration: new labels or an Anglo-Saxon educational system for the Netherlands?]. TH\&MA, 4, 25-29.

Van Merriënboer, J. J. G. (1999). Cognition and multimedia design for complex learning. (Inaugural address available from the Educational Technology Expertise Center of the Open University of the Netherlands, PO Box 2960, 6401 DL, Heerlen, The Netherlands)

Von Glasersfeld, E. (1988). Cognition, construction of knowledge and teaching. (Eric Document Reproduction Service No. ED 294 754).

Woolridge, R. L. (1987) Factors influencing recent growth and expansion. In K.G. Ryder and J.W. Wilson (Eds.) Cooperative education in a new era (pp. 13-29). San Francisco: Jossey-Bass. 


\section{Notes:}

1 The Larousse dictionary defines dualism as that view which seeks to explain the world by the assumption of two radically independent and absolute elements, e.g. (1) the doctrine of the entire separation of spirit

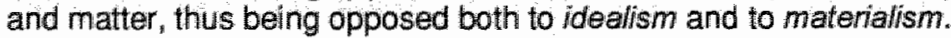

In reaction to a proposed law in Maryland and other states in the United States barring same sex marriages William $O$. Breenan wrote "What are you? Male, Merm, Herm, Ferm or Female?" in the Baltimore Morning Sun on March 17, 1996. According to his sources: "This attempt to deny marriage to all but culturally defined males and females through legislating science is eventually doomed to failure because a two-category male/temale system can never encompass the variety of human gender construction." See http:/songweaver.com/gender/whatru.htm/

Dr. Sterling Fausto (Myths of Gender: Biological Theories About Women and Men, 1992) speaks of a smooth continuum between $100 \%$ biologically male and $100 \%$ biologically female. She posits that between $1.7 \%$ (conservative estimate: http://www. isna.org/fag.html) and $4 \%$ (bold estimate) of the population are intersexual (a difference between anatomic, endocrine and genetic sex). That is 17,000 people per million. In comparison there are 4 Siamese twins, 1000 people with Down's syndrome and 1400 people with harelip per million in the population.

Wave-particle dualify is the circumstance that light and other electromagnetic radiation behave like a wave motion when being propagated and like particles when interacting with matter.

Other educational dualities are:

$\begin{array}{lll}\text { student } & \Leftrightarrow \text { teacher } \\ \text { teaching } & \Leftrightarrow \text { learning } \\ \text { contiguous } & \Leftrightarrow \text { at a distance } \\ \text { centralized } & \Leftrightarrow \text { distributed } \\ \text { classroom/theory } & \Leftrightarrow \text { laboratory/practice } \\ \text { institutional } & \Leftrightarrow \text { in-service } \\ \text { polytechnic } & \Leftrightarrow \text { university } \\ \text { academic } & \Leftrightarrow \text { school-like } \\ \text { school } & \Leftrightarrow \text { real world }\end{array}$

In 1657, the first Science Society was founded in Florence, Italy. Its goal was to be a forum for scientists for consultation and discussion with the goall of promoting experimental learning in the Natural

Sciences. In 1796 a similar society, the Dublin Society, went as far as 
setting up a chemical laboratory. With the onset of the nineteenth century the educational establishment, with Germany in the forefront, began to use the laboratory in Natural Sciences education. Student use of laboratories was more the exception than the rule. Except for practical courses in medical schools, probably the first laboratory in which the experimental methods of chemistry were taught systematically to students was established by Justus von Liebig at the University of Giessen in 1824 (Phillips, 1981). The first student laboratory in Britain was set up at the Royal Technical College in 1830, (Lock, 1988) although Lord Kelvin claimed that the first chemistry laboratories for students were established at the University of Glasgow prior to this (Phillips, 1981).

In 1918, the Thomson Committee, reporting on Natural Sciences as taught in schools, stated, ". . . in many schools more time is spent in laboratory work than the results obtained can justify. . . [although] it is an essential part of science teaching ... sometimes the performance of laboratory exercises has been considered too much an end in itself . . . [losing] educational value." (Thomson Report in Kerr, 1964).

The launching of Sputnik in 1957 signaled the onset of an increase in cooperative efforts between specialists in science and specialists in education to improve science teaching, the so-called 'Sputnik shock'. In the last years of that decade as well as in the 1960's and 1970's a number of cooperative projects in the United States and in Great Britain were designed with new rationales for the use of laboratories. Some results of this movement were:

The Nuffield Foundation sponsored a project of curriculum development and reform in the Natural Sciences in Great Britain.

The Physical Science Study Committee (PSSC) which produced its first learning materials in 1960 to improve the teaching of physics.

The Biological Sciences Curriculum Study (BSCS), which began its activities in January 1959 under the sponsorship of the American Institute of Biological Sciences was organized to improve biological education al all levels of instruction.

The Chemical Education Material Study (CHEM Study) was established in 1959 by the American Chemical Society.

Pragmatism is an indigenous American phillosophical theory that explains both meaning and truth in terms of the application of ideas or belliefs to the performance of actions that have observable practical outcomes. One aspect of this philosophy, fallibilism, holds that any proposition accepted as an item of knowledge has this status only 
provisionally, contingent upon its adequacy in providing a coherent understanding of the world as the basis for human action.

This description of Project Centered Learning (originally called Project Oriented Education) comes from a memorandum entitled "Real Company Education in the School of Knowledge Engineering: A vision of Project Oriented Education" from the Educational Unit of the Faculty of General Sciences; specifically from Dr. J. Perrenet, Dr. R. van Houten and Drs. V. Neevel. My thanks to them for teaching me about this form of education!

Professor. dr. Roel in 4 Veld in an interview in Observant (November $11,1999)$ stated that "'knowledge is as perishable as fresh fish and memory is poor. Students anly need to learn a few things before they begin their professional careers. The need to acquire a starting qualification and the power to continue to learn. ... What do students need from a course on 'giving leadership"? in their first job they will have more profit from a course on 'taking leadership', so that they realize that the secretary in an institution is often much more important than they are.

Also, in a recent article in the Science Supplement of the NRC Handelsblad (April 22, 2000), Prof. Frits van Oostrom lamented that "In schooling universities are good, very good or even excellent, but in personal development we are painfully poor."

This idea of cooperative education should not be confused with cooperative learning. Cooperative learning is the instructional use of small groups so that students work together to maximize their own and each others' learning. Carefully structured cooperative learning involves people working in teams to accomplish a common goal, under conditions that involve both positive interdependence (all members must cooperate to complete the task) and individual group accountability (each member is accountable for the complete final outcome) (Johnson, Johnson, \& Smith, 1991).

Cash (1987) found, for example that $100 \%$ of the coop students that he followed had full-time employment within one month of graduation ( $67 \%$ of the non-coop students had achieved the same) $100 \%$ felt that they were not underemployed (vs. $67 \%$ ), $89 \%$ were satisfied with salary and benefits (vs. $50 \%$ ) and $100 \%$ were satisfied with career potential (vs. 62\%).

In a 1980 analysis of the Cooperative education program at Southern Bell in which the productivity and costs of cooperative education students in their third through seventh semester were compared with "fully productive" engineers (with quality being judged as fairly equal) it 
was found that value of the students, after salaries, was $\$ 8000$ per student annually.

This idea of $3+2$ has been met with mixed reviews by academia. For some it is seen as a way back to the old system of a five year doctoral study which was very rudely interrupted by the previous minister of education for economic rather than educational reasons. For others it is seen as a shrewd trick by the present minister of education to reduce the subsidy paid to educational institutions from four years (the present length of doctoral study) to three years. The argument being that since the three year bachelors diploma conveys a societally accepted diploma, the costs for further education (the +2 ) should now be carried by the students themselves or by industry.

This working group is composed of: Hildegard Schneider (Law), Arnold Labrie (Cultural Sciences), Christiaan Wolff (Economics), Gerard Dunselman Medicine), Jan Vermunt (Health Sciences), Harm Hospers (Psychology), Renée Speijcken, Hans Philipsen and myselff (General Sciences).

According to Prof. Henk Schmidt (personal communication) who recently competed a large scale study of alumni of Maastricht University, alumni are more competent than graduates of traditional universities with respect to professional skills, such as solving problems, working with others, sociability, studying independently, finding and using source materials, producing ideas to work better, helping colleagues, working independently and planning.

In that plan, the minister specifically referred to the natural and technical sciences as areas where cooperative education should be implemented. His reasons were that it is a way to improve the qualitative connection to the job market and that it can provide support for the integration of the student's technical knowledge with the social and commercial skills necessary in the workplace.

In reality, post secondary cooperative education curricula originated as pedagogy to ensure that students received the most comprehensive, effective and high academic learning to prepare them for their future careers. This was seen as equally vital for top academic performers as for other students (National Commission for Cooperative Education, 2000).

The Mission Statement of Maastricht University states:

Maastricht University is an institution of academic education and research. It has two dominant profile characteristics: small scale student oriented education (PBL) and internationalization, The University stands for: 
- educational innovation:

- pursuance of high quality education, research and social service that measures up to international standards;

- an international orientation, not only through its quality of education and research, but also through the content of its programs and the nature of its academic and social life;

- a contribution to the economic, social and cultural development of the (Eu)region.

In the October 1998 issue of DocUMent, Simon Vermeer student member of the Maastricht University Council stated: In spite of the possible sticking points, in my opinion primarily practical in nature, 1 think that cooperative education can add something to the educational activities of the university. The introduction of cooperative education can be the beginning of personalized study. To keep pace, the university may not shy away from this development and should actually play a pioneer's role, especially when you consider that educational innovation is an important cornerstone of Maastricht University.

Although information was a key factor, Laycock el al (1992) found that, strangely enough, the quality of the supervisors was not a key factor. A good supervisor will not guarantee a successful experience; a poor supervisor will not necessarily result in an unsuccessful experience.

In describing the relationship between women, Simone de Beauvoir wrote: Between women love is contemplative. There is no struggle, no victory, no defeat; in exact reciprocity each is at once subject and object, sovereign and slave; duality becomes mutuality. Le Deuxième Sexe (trans. The Second Sex). 